\title{
PENGARUH WAKTU PERENDAMAN DAN KONSENTRASI KARBOKSIMETIL KITOSAN UNTUK MENURUNKAN KANDUNGAN LOGAM BERAT Hg, Cd, dan Pb PADA KERANG HIJAU (Perna viridis Linn.)
}

\author{
Jovita Tri Murtini"), Ahmad Dwi Kurniawan ${ }^{* *}$, dan Eko Nurcahya Dewi"*)
}

\begin{abstract}
ABSTRAK
Penelitian telah dilakukan untuk mengetahui pengaruh waktu perendaman dan konsentrasi karboksimetil kitosan larut air (KMK) terhadap kandungan logam berat $\mathrm{Hg}$, $\mathrm{Cd}$, dan $\mathrm{Pb}$ pada daging kerang hijau (Perna viridis Linn.). Perlakuan perendaman larutan karboksimetil kitosan menggunakan konsentrasi $0 ; 0,5 ; 1$; dan $1,5 \%$ dengan lama perendaman 1,2 , dan 3 jam. Hasil penelitian menunjukkan bahwa perlakuan yang paling efektif untuk penurunan logam $\mathrm{Hg}$ adalah perendaman dengan larutan KMK $0,5 \%$ selama 1 jam, sedangkan perlakuan yang paling efektif untuk penurunan $\mathrm{Pb}$ adalah perendaman dengan larutan $\mathrm{KMK} 0,5 \%$ selama 3 jam. Hasil penelitian juga menunjukkan bahwa KMK tidak efektif untuk menurunkan $\mathrm{Cd}$ pada kerang hijau. Analisis sidik ragam menunjukkan tidak ada interaksi antara konsentrasi KMK dengan lama perendaman yang dapat menurunkan kandungan $\mathrm{Hg}$ dan $\mathrm{Cd}$, tetapi terdapat interaksi yang sangat nyata antara konsentrasi KMK dan lama perendaman untuk menurunkan kandungan $\mathrm{Pb}$. Perendaman dalam akuades (KMK 0\%) sudah dapat menurunkan kandungan logam berat dalam kerang hijau, diduga karena terjadinya leaching dari senyawa organik yang berikatan dengan logam berat.
\end{abstract}

ABSTRACT: Effect of dipping time and carboxymethyl chitosan concentration on the reduction of $\mathrm{Hg}, \mathrm{Cd}$, and $\mathrm{Pb}$ content in green mussel (Perna viridis Linn.). By: Jovita Tri Murtini, Ahmad Dwi Kurniawan, and Eko Nurcahya Dewi

Research was conducted to find out the effect of dipping time and concentration of water soluble carboxymethyl chitosan (CMCts) to decrease the level of mercury ( $\mathrm{Hg})$, cadmium (Cd), and lead $(\mathrm{Pb})$ content in green mussel (Perna viridis Linn.). Concentrations of CMCts used were 0 ; 0.5; 1; and 1.5\%, whereas dipping time used were 1, 2, and 3 hours respectively. The results showed that dipping in $0.5 \%$ CMCts for 1 hour was the most effective treatment, while the most effective treatment for decreasing Pb content was dipping in CMCts $1.5 \%$ for 3 hour. Results of the study also revealed that CMCts was not effective to reduce $\mathrm{Cd}$ in green mussel. Analysis of variance showed that there was no interaction between concentration of CMCts and dipping time in reducing of $\mathrm{Hg}$ and $\mathrm{Cd}$ content, but concentration of CMCts and dipping time have highly significant interaction in reducing Pb content. Dipping of the mussel in aquadest (KMK $0 \%$ ) was able to reduce heavy metal contents of green mussel presurnably due to the leaching of the metal bond organic substances.

KEYWORDS: green mussel, carboxymethyl chitosan, $\mathrm{Hg}, \mathrm{Cd}$, and Pb content

\section{PENDAHULUAN}

Kerang hijau (Perna viridis Linn.) merupakan salah satu komoditas perikanan yang sudah lama dikenal dan dewasa ini kerang jenis tersebut telah banyak dibudidayakan. Teknik budidayanya mudah dikerjakan, tidak memerlukan modal yang besar, dan dapat dipanen setelah berumur 6-7 bulan. Hasil panen kerang hijau per hektar per tahun dapat mencapai 200300 ton kerang utuh atau sekitar $60-100$ ton daging kerang (Porsepwandi, 1998).
Sebagaimana halnya produk perikanan lain, kekerangan sering menghadapi masalah dengan pencemaran oleh logam berat. Kandungan logam berat yang tinggi ditemukan pada jenis kerang-kerangan karena organisme ini merupakan organisme invertebrata filter feeder dan hidup menetap, juga dikemukakan bahwa kandungan logam berat dalam daging organisme perairan biasanya lebih tinggi daripada kandungan logam berat pada perairannya sendiri, karena logam berat tersebut akan terakumulasi di dalam dagingnya (Hutagalung, 1991).

\footnotetext{
Peneliti pada Balai Besar Riset Pengolahan Produk dan Bioteknologi Kelautan dan Perikanan, DKP

*) Mahasiswa Fakultas Perikanan dan IImu Kelautan Universitas Diponegoro

- Dosen Fakultas Perikanan dan IImu Kelautan Universitas Diponegoro
} 
Menurut Darmono (1995), urutan toksisitas logam berat dari yang tertinggi ke yang paling rendah terhadap manusia yang mengkonsumsi ikan yang tercemar adalah $\mathrm{Hg}^{2+}>\mathrm{Cd}^{2+}>\mathrm{Ag}^{2+}>\mathrm{Ni}^{2+}>\mathrm{Pb}^{2+}>$ $\mathrm{As}^{2+}>\mathrm{Zn}^{2+}$.

Pencemaran logam berat $\mathrm{Hg}, \mathrm{Cd}$, dan $\mathrm{Pb}$ pada daging kerang hijau akan menyebabkan keracunan bagi masyarakat yang mengkonsumsinya karena logam berat tersebut termasuk jenis logam berat yang mempunyai tingkat toksisitas tinggi serta bersifat menumpuk/akumulatif pada tubuh manusia yang mengkonsumsinya. Menurut LeCoultre (2001), akibat yang ditimbulkan karena keracunan logam berat $\mathrm{Hg}$ antara lain adalah kerusakan syaraf (neurotoksik) dan kerusakan pada kromosom yang dapat mengakibatkan kemandulan (teratotoksik), sedangkan akibat yang ditimbulkan oleh keracunan $\mathrm{Cd}$ adalah kerusakan hati, ginjal, paru-paru, dan tulang serta bersifat karsinogen. Keracunan logam $\mathrm{Pb}$ akan menyebabkan kerusakan paru-paru dan kerusakan syaraf. Oleh karena itu, perlu adanya suatu upaya untuk menurunkan kandungan logam berat pada daging kerang hijau sehingga pengaruh negatif terhadap kesehatan masyarakat yang mengkonsumsinya dapat dicegah secara dini.

Berbagai metode seperti penukaran ion, penyerapan dengan karbon aktif, dan pengendapan secara elektrolisis telah dilakukan untuk menyerap bahan pencemar beracun, tetapi cara ini membutuhkan biaya yang besar dalam pengoperasiannya (Marganof, 2003). Irwansyah (1995) menyatakan bahwa salah satu upaya menurunkan kadar logam berat pada daging kerang hijau yaitu dengan merendam daging kerang tersebut dalam larutan $\mathrm{Na}_{2} \mathrm{CaEDTA}$ (dinatrium kalsium etilen diamin tetra-asetat) dan kitosan karena kedua zat ini mempunyai kemampuan untuk mengikat ion logam berat dan menariknya keluar jaringan. Murtini et al. (2004), mengatakan bahwa konsentrasi larutan kitosan 1,5\% dengan lama perendaman 3 jam cukup efektif mereduksi logam berat $\mathrm{Hg}$ sebesar $94,89 \%$ dan logam $\mathrm{Pb}$ sebesar 96,48\% daging kerang hijau. Adanya sifat-sifat kitin dan derivatnya yang dihubungkan dengan adanya gugus amino dan hidroksil yang terikat, menyebabkan kitin dan kitosan serta turunannya mempunyai reaktifitas kimia yang tinggi dan menyebabkan sifat polielektrolit kation sehingga dapat berperan sebagai penukar ion (ion exchanger) dan dapat berperan sebagai adsorben terhadap logam berat (Rinaudo \& Domard, 1989). Berdasarkan sifat-sifat yang dimiliki oleh kitosan sebagai adsorben logam berat, pada penelitian ini dicoba dengan menggunakan karboksimetil kitosan yang merupakan salah satu senyawa derivat dari kitosan yang mampu larut dalam air dan tidak beracun.
Karboksimetil kitosan mempunyai keistimewaan dapat larut dalam air, bersifat biodegradable, biocompatible, tidak beracun, dan hidrofilik.

Tujuan dilakukannya penelitian ini adalah untuk mengetahui pengaruh karboksimetil kitosan dalam menurunkan kandungan logam berat $\mathrm{Hg}, \mathrm{Cd}$, dan $\mathrm{Pb}$ pada daging kerang hijau (Perna viridis Linn.).

\section{BAHAN DAN METODE}

\section{Bahan}

Bahan yang digunakan dalam penelitian ini adalah kerang hijau (Perna viridis Linn.) dalam keadaan hidup yang diperoleh dari lokasi budidaya di perairan Muara Dadap, Jakarta. Kerang hijau hidup dimasukkan dalam boks tanpa air dibawa ke laboratorium Balai Besar Riset Pengolahan Produk dan Bioteknologi Kelautan dan Perikanan, Jakarta. Kitosan dari cangkang kepiting digunakan untuk membuat karboksilmetil kitosan (KMK) dengan menggunakan metode yang digunakan Dwiyitno et al. (2004).

\section{Metode}

Kerang bercangkang yang masih hidup diambil dagingnya, kemudian ditimbang untuk masing-masing perlakuan setelah itu daging kerang direndam dalam larutan KMK dalam air dengan konsentrasi 0; 0,5; 1,0; dan $1,5 \%$ selama 1, 2, dan 3 jam.

Parameter yang diamati adalah kadar air (metode oven $105^{\circ} \mathrm{C}$ selama 24 jam), kadar abu (muffle furnace $550^{\circ} \mathrm{C}$ ), viskositas (Kyoon et al., 2003), kelarutan (gravimetri), derajat deasetilasi (Muzzarelli et al., 1997), derajat substitusi (Anon., 1998), dan kadar logam $\mathrm{Hg}, \mathrm{Cd}$, dan $\mathrm{Pb}$. Analisis logam $\mathrm{Hg}, \mathrm{Cd}$, dan $\mathrm{Pb}$ dilakukan dengan menggunakan Atomic Absorbtion Spectrophotometry (AAS) Perkin Elmer AAnalyst 800. Preparasi contoh menggunakan metode yang disajikan Hutagalung et al. (1997).

Analisis data menggunakan rancangan acak lengkap faktorial dengan 2 faktor dan 3 kali ulangan, dengan membandingkan antar perlakuan yaitu konsentrasi dan waktu perendaman.

\section{HASIL DAN BAHASAN}

Hasil analisis fisika kimia karboksimetil kitosan yang digunakan dalam penelitian ini disajikan pada Tabel 1.

Dari Tabel 1 dapat dilihat bahwa sifat fisiko kimia karboksimetil kitosan yang dihasilkan telah memenuhi standar (Protan Laboratories Inc., 1987 dalam Setyahadi, 2006). Karboksimetil kitosan yang 
Tabel 1. Hasil analisis fisiko kimia karboksimetil kitosan

Table 1. Results of physico chemical analysis of carboxymethyl chitosan

\begin{tabular}{lcc}
\hline \multicolumn{1}{c}{ Parameter/Parameters } & Nilai/Value & Standar/Standard $^{*}$ ) \\
\hline Kadar air/Moisture content (\%) & 8.00 & 10.00 \\
Kadar abu/Ash content (\%) & 0.11 & 0.50 \\
Viskositas/Viscosity (cPs) & 30.00 & $<200.00$ \\
Kelarutan/Solubility (\%) & 99.34 & 100.00 \\
Derajat deasetilasi/Degree of deacetilation (\%) & 58.87 & - \\
Derajat substitusi/Degree of substitution & 1.64 & $>0.45$ \\
\hline
\end{tabular}

*) Protan Laboratories Inc., 1987 (Setyahadi, 2006)

dihasilkan encer karena mempunyai viskositas di bawah $200 \mathrm{cPs}$. Seperti halnya kitosan, viskositas KMK juga tergantung pada aplikasi komersialnya. Viskositas KMK ini dipengaruhi oleh proses esterifikasi, yaitu semakin lama dan semakin tinggi suhu yang digunakan, viskositas akan semakin rendah. Suhu pada proses ini berperan sebagai katalis untuk mempercepat subtitusi $-\mathrm{H}$ dari gugus $-\mathrm{CH}_{2} \mathrm{OH}$ dan $-\mathrm{NH}_{2}$ dengan $\mathrm{CH}_{3} \mathrm{COOH}$ dari asam monokloroasetat yang ditambahkan. Kelarutan karboksimetil kitosan sangat ditentukan oleh keberhasilan reaksi esterifikasi dengan monokloroasetat. Semakin banyak gugus $\mathrm{CH}_{3} \mathrm{COOH}$ yang mensubstitusi ion $\mathrm{H}+$ pada gugus hidroksil maupun amina, maka kelarutan KMK semakin tinggi (Dwiyitno et al., 2004).

Untuk mengetahui kelarutan KMK yang digunakan dapat dilihat dari nilai derajat substitusi. Derajat subtitusi (DS) KMK adalah 1,64 (Tabel 1). Derajat substitusi tersebut menyatakan jumlah gugus hidroksil dan amin per unit ulang glukosa anhidrat yang disubstitusi oleh karboksimetil. Nilai derajat substitusi berkisar antara 0-3,00 dan biasanya bukan merupakan bilangan bulat karena harga tersebut menyatakan harga rata-rata dari keseluruhan sampel (Martin et al., 1983). KMK yang mempunyai DS $\leq$ 0,30 bersifat tidak larut dalam air sedangkan KMK dengan $\mathrm{DS} \geq 0,45$ mampu larut dalam air (Oktavia et al., 2005).

Hasil analisis logam berat $\mathrm{Hg}, \mathrm{Cd}$, dan $\mathrm{Pb}$ pada daging kerang hijau (Perna viridis Linn.) yang diperoleh dari Muara Dadap, Jakarta sebelum diberi perlakuan adalah sebagai berikut: kandungan logam merkuri $(\mathrm{Hg})$ sebesar 13,40 ppb, kandungan logam kadmium (Cd) adalah $32,30 \mathrm{ppb}$, dan kandungan logam timbal $(\mathrm{Pb})$ adalah $21,60 \mathrm{ppb}$. Walaupun kadar logam berat tersebut masih di bawah ambang batas yang ditetapkan, tetap perlu diwaspadai efek bioakumulasinya di dalam tubuh manusia yang mengkonsumsinya. Kandungan awal logam berat $\mathrm{Hg}$,
$\mathrm{Cd}$, dan $\mathrm{Pb}$ kerang hijau tersebut masih di bawah ambang batas yang ditetapkan oleh Kep. Ditjen POM No.03725/B/SK/VII/1989 dan FAO/WHO yaitu sebesar 500 ppb untuk logam $\mathrm{Hg}, 1.000$ ppb untuk logam $\mathrm{Cd}$, dan 2.000 ppb untuk logam $\mathrm{Pb}$.

Irwansyah (1995) menyatakan bahwa perairan Muara Kamal yang letaknya berdekatan dengan Muara Dadap telah mengandung $\mathrm{Hg}$ dengan rata-rata 10,7 ppb. Menurut Porsepwandi (1998) kerang hijau yang dibudidayakan di Muara Kamal Teluk Jakarta mengandung $\mathrm{Hg} 3,95$ ppb. Penelitian Lestari (2002), pada bulan Januari 2002, kandungan $\mathrm{Hg}$ pada daging kerang hijau sebesar 5,37 ppb. Sedangkan menurut penelitian Murtini et al. (2004) kandungan Hg pada kerang hijau yang diperoleh dari perairan Muara Dadap adalah sebesar 16,04 ppb. Muara Dadap dan Muara Kamal adalah merupakan bagian dari Teluk Jakarta, kemungkinan meningkatnya kadar logam berat tersebut diduga disebabkan karena semakin tingginya tingkat pencemaran air di perairan Teluk Jakarta, mengingat semakin banyaknya industri-industri yang ada di Jakarta. Menurut Wahyuni \& Widiyanti (2004), di Jakarta terdapat lebih dari 2.000 industri dan diperkirakan hingga saat ini sekitar $80 \%$ di antaranya tidak mempunyai sarana pengolahan dan pembuangan limbah yang aman dan memadai. Industri-industri seperti industri tekstil, elektronik, baterai, cat, dan pengolahan logam merupakan penghasil limbah yang mengandung logam berat $\mathrm{Hg}$, $\mathrm{Cd}$, dan $\mathrm{Pb}$ yang membuang limbahnya langsung tanpa melalui proses pengolahan limbah terlebih dahulu ke sungai-sungai yang bermuara di Teluk Jakarta. Sungai-sungai tersebut antara lain Sungai Angke, Sungai Ciliwung, Sungai Sunter, Sungai Bekasi, Sungai Priok, dan Sungai Marunda.

Hasil analisis kandungan logam berat $\mathrm{Hg}$, $\mathrm{Cd}$, dan $\mathrm{Pb}$ pada daging kerang hijau dari kombinasi perlakuan variasi konsentrasi KMK dan variasi waktu perendaman disajikan pada Tabel 2. 
Tabel 2. Kandungan logam berat $\mathrm{Hg}, \mathrm{Cd}$, dan $\mathrm{Pb}(\mathrm{ppb})$ pada daging kerang hijau (Perna viridis Linn.) setelah perlakuan dengan $\mathrm{KMK}$

Table 2. Heavy metals $(\mathrm{Hg}, \mathrm{Cd}$, and $\mathrm{Pb}$ ) content of green mussel (Perna viridis Linn.) after treated with CMCts

\begin{tabular}{ccccc}
\hline \multirow{2}{*}{$\begin{array}{c}\text { Konsentrasi KMKI } \\
\text { CMCts concentration }\end{array}$} & \multirow{2}{*}{$\begin{array}{c}\text { Waktu perendaman (jam) } \\
\text { Dipping time (hour) }\end{array}$} & \multicolumn{3}{c}{$\begin{array}{c}\text { Kandungan logam berat/ } \\
\text { Heavy metal content (ppb) }\end{array}$} \\
\cline { 3 - 5 } & & $\mathbf{H g}$ & $\mathbf{C d}$ & $\mathbf{P b}$ \\
\hline \multirow{2}{*}{$0 \%$} & 1 & 5.19 & 19.29 & 14.14 \\
& 2 & 6.91 & 16.17 & 13.17 \\
$0.50 \%$ & 3 & 7.23 & 16.36 & 5.52 \\
\hline \multirow{2}{*}{$1.00 \%$} & 1 & 2.34 & 20.94 & 14.81 \\
& 2 & 2.67 & 16.21 & 12.89 \\
& 3 & 3.52 & 18.58 & 4.53 \\
\hline \multirow{2}{*}{$1.50 \%$} & 1 & 3.76 & 20.31 & 11.23 \\
& 2 & 2.55 & 17.25 & 12.86 \\
& 3 & 4.77 & 15.16 & 4.41 \\
\hline & 1 & 3.97 & 18.57 & 11.92 \\
& 2 & 2.03 & 16.68 & 4.24 \\
& 3 & 3.86 & 14.52 & 3.95 \\
\hline
\end{tabular}

Catatan/Note: Kandungan logam berat sebelum perlakuan adalah: $\mathrm{Hg}$ (13,40 ppb), Cd (32,30 ppb), dan $\mathrm{Pb}$ (21,60 ppb)/Heavy metal content before treatment: $\mathrm{Hg}$ (13.40 ppb); Cd (32.30 ppb); and Pb (21.60 ppb)

Berdasarkan uji Duncan, perlakuan perendaman dalam larutan KMK 0,5; 1 ; dan 1,5\% tidak berbeda nyata terhadap tingkat penurunan logam $\mathrm{Hg}$ pada daging kerang hijau, sedangkan kadar Hg pada lama perendaman 1 dan 2 jam berbeda nyata dan lebih rendah dibandingkan lama perendaman 3 jam, maka perlakuan yang efektif untuk menurunkan kandungan $\mathrm{Hg}$ adalah perendaman dengan larutan KMK 0,5\% selama 1 jam dengan tingkat penurunan sebesar

$82,54 \%$ (Gambar 1). Hasil analisis sidik ragam memperlihatkan perbedaan konsentrasi berpengaruh sangat nyata, sedangkan lama perendaman berpengaruh nyata terhadap tingkat penurunan logam berat $\mathrm{Hg}$. Analisis sidik ragam memperlihatkan tidak ada interaksi yang nyata antara masing-masing faktor.

Namun demikian, terlihat bahwa perendaman dalam larutan KMK 0\% atau dalam akuades saja sudah menurunkan kandungan logam berat sebanyak

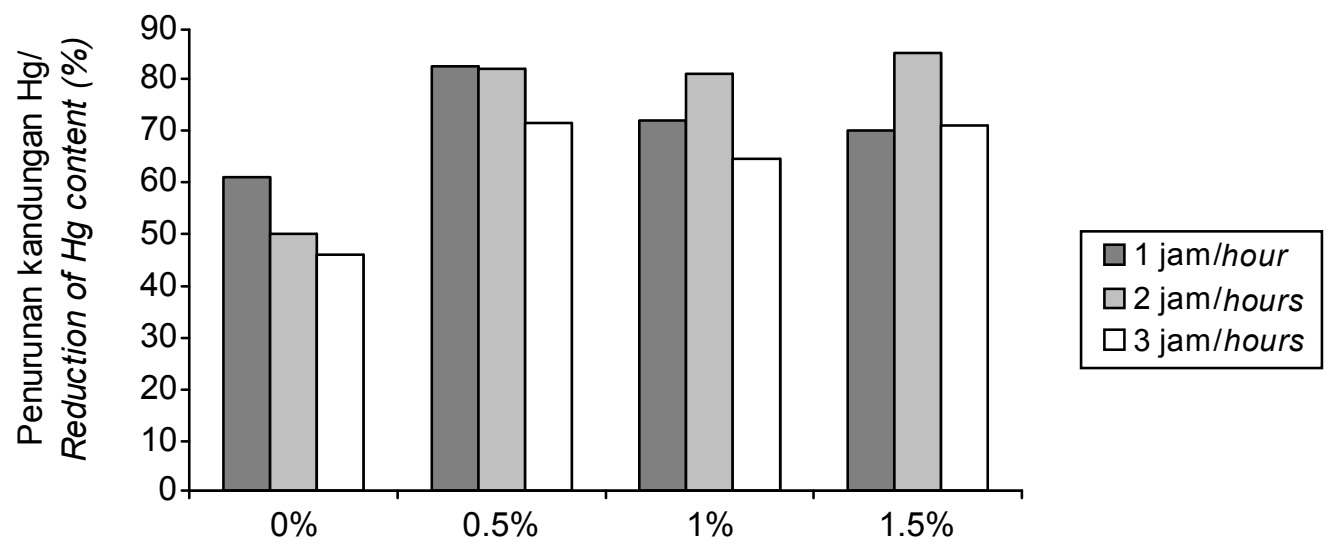

Konsentrasi KMK/CMCts concentrations

Gambar 1. Pengaruh perendaman larutan KMK terhadap penurunan kandungan $\mathrm{Hg}$ daging kerang hijau (Perna viridis Linn.).

Figure 1. Effect of dipping of green mussel (Perna viridis Linn.) in CMCts solution on the reduction of $\mathrm{Hg}$ content. 
50-60\%, sehingga sebenarnya peran KMK dalam menurunkan kandungan $\mathrm{Hg}$ hanya sebesar $20-30 \%$.

Penurunan kandungan $\mathrm{Hg}$ pada perendaman dalam akuades diduga merupakan akibat terlepasnya ion logam dari struktur protein kerang hijau yang kemudian terlarut keluar (leaching) dari daging kerang hijau sebagai upaya penyeimbang konsentrasi dalam daging kerang. Secara alamiah, laju pertukaran ion logam dengan lingkungannya sangat mudah terutama ion logam yang berikatan metalloprotein karena ikatan logam ini sangat labil (Wahyuni \& Widiyanti, 2004).

Penurunan kandungan logam berat $\mathrm{Hg}$ disebabkan karena larutan KMK membentuk ikatan kompleks dengan ion logam berat tersebut. Meskipun tidak setinggi penurunan $\mathrm{Hg}$ karena perendaman dalam akuades, pengaruh KMK dalam menurunkan logam $\mathrm{Hg}$ merupakan yang tertinggi bila dibandingkan dengan tingkat penurunan logam berat $\mathrm{Cd}$ dan $\mathrm{Pb}$. $\mathrm{Hal}$ ini diduga karena $\mathrm{Hg}$ membentuk ikatan metalloprotein yang mudah terputus ikatan proteinnya. Menurut Darmono (1995), pada sistem ikatan metalloprotein, ikatan logamnya sangat labil sehingga laju pertukaran ion dengan lingkungannya sangat mudah terjadi. Faktor lain adalah terjadinya proses denaturasi protein karena pengaruh $\mathrm{pH}$ larutan $\mathrm{KMK}$ yang berkisar antara 4-5, pada kondisi asam ikatan kompleks antara logam dan protein akan terlepas. Proses denaturasi akan mengubah konfigurasi struktur protein, dari bentuk yang sangat kompleks menjadi bentuk yang lebih sederhana (Wahyuni \& Widiyanti, 2004).

Menurut Fessenden \& Fessenden (1995), denaturasi dapat bersifat reversible jika suatu protein hanya dikenai kondisi denaturasi seperti perubahan $\mathrm{pH}$ asam yang tidak besar. Proses kembalinya protein memperoleh struktur lebih tinggi secara alamiahnya disebut dengan renaturasi, dengan alasan inilah mengapa pada perendaman 3 jam mempunyai kandungan $\mathrm{Hg}$ lebih tinggi daripada perlakuan perendaman 1 dan $2 \mathrm{jam}$. Setelah perendaman $2 \mathrm{jam}$, diduga terjadi renaturasi pada protein sehingga protein akan mempunyai kemampuan alamiahnya mengikat kembali logam $\mathrm{Hg}$. Selain itu diduga $\mathrm{Hg}$ yang terkandung dalam larutan KMK (Tabel 3) teradsorbsi pada daging kerang hijau, sehingga meningkatkan kadar logam berat $\mathrm{Hg}$ pada daging kerang hijau.

Tabel 3. Kandungan logam berat pada larutan karboksimetil kitosan

Table 3. Heavy metal content of carboxymethyl chitosan solution

\begin{tabular}{lccc}
\hline $\begin{array}{c}\text { Larutan perendam/ } \\
\text { Dipping solution }\end{array}$ & \multicolumn{3}{c}{ Kandungan logam berat/Heavy metal content (ppb) } \\
\cline { 2 - 4 } & $\mathbf{H g}$ & $\mathbf{C d}$ & $\mathbf{P b}$ \\
\hline KMK/CMCts 0.5\% & 0.120 & 0.050 & 0.005 \\
KMK/CMCts 1.0\% & 0.240 & 0.100 & 0.011 \\
KMK/CMCts 1.5\% & 0.370 & 0.150 & 0.017 \\
\hline
\end{tabular}

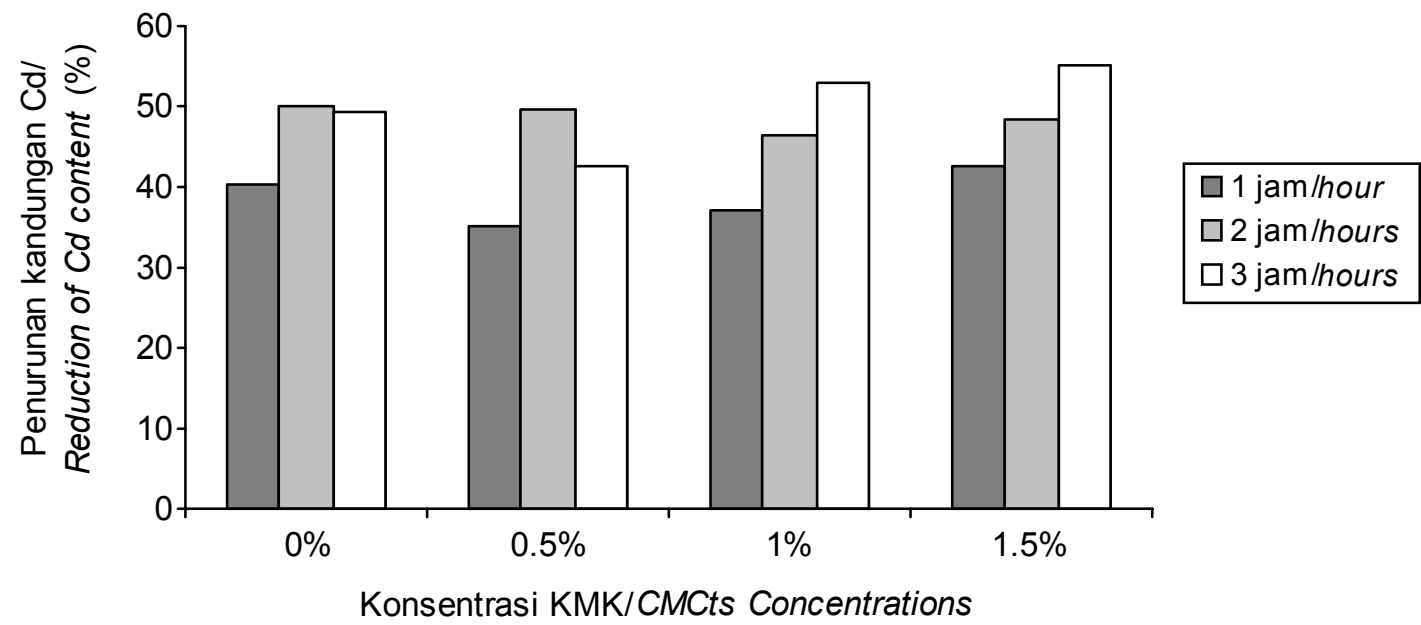

Gambar 2. Pengaruh perendaman larutan KMK terhadap penurunan kandungan Cd daging kerang hijau (Perna viridis Linn.).

Figure 2. Effect of dipping of green mussel (Perna viridis Linn.) in CMCts solution on the reduction of Cd content. 
Untuk penurunan logam Cd, hasil uji Duncan memperlihatkan bahwa konsentrasi KMK 0; 0,5; 1 ; dan $1,5 \%$ menunjukkan tidak adanya pengaruh yang nyata, sedangkan lama perendaman 2 dan 3 jam menunjukkan perbedaan sangat nyata dan lebih besar dibandingkan dengan lama perendaman 1 jam. Analisis sidik ragam menunjukkan bahwa perlakuan perendaman dengan konsentrasi KMK yang berbeda tidak berpengaruh nyata terhadap tingkat pengurangan logam berat $\mathrm{Cd}$, sedangkan lama perendaman berpengaruh sangat nyata. Hasil ini menunjukkan bahwa perendaman dalam akuades ternyata sudah menurunkan kandungan Cd hingga 80\%, dan KMK tidak berperanan dalam penurunan kandungan $\mathrm{Cd}$. Penurunan kandungan $\mathrm{Cd}$ karena perendaman diduga karena alasan yang sama dengan terjadinya penurunan kandungan $\mathrm{Hg}$, sedangkan ketidak berhasilan KMK dalam menurunkan kandungan $\mathrm{Cd}$ diduga karena $\mathrm{Cd}$ dan protein membentuk ikatan metalloenzim. Menurut Darmono (1995), metalloenzim merupakan sub kelas dari metalloprotein, yang proteinnya berikatan kuat dengan ion logam sehingga mempunyai ikatan yang kuat dan stabil. Hal ini dikarenakan ion logam menjadi bagian dari struktur protein yang hanya dapat lepas dalam keadaan istimewa. Faktor lain penyebab rendahnya tingkat penurunan logam $\mathrm{Cd}$ pada daging kerang hijau adalah pada larutan KMK terdapat kandungan $\mathrm{Cd}$ (Tabel 3), sehingga kemampuan KMK untuk mengikat logam Cd ikut berkurang.

Hal yang sama terjadi pada penurunan kandungan $\mathrm{Pb}$ (Gambar 3). Dengan perendaman tanpa KMK, kandungan $\mathrm{Pb}$ dapat diturunkan antara $34,5-74,4 \%$ tergantung lama perendaman. Adapun KMK hanya menambah penurunan sebesar 4,6-13,5\% tergantung lama perendaman. Pengaruh lama perendaman sangat nyata dalam menurunkan kandungan $\mathrm{Pb}$. Analisis sidik ragam memperlihatkan bahwa terdapat interaksi sangat nyata antara faktor konsentrasi KMK dengan lama perendaman terhadap tingkat penurunan logam $\mathrm{Pb}$ pada daging kerang hijau dan masingmasing faktor berpengaruh sangat nyata terhadap tingkat penurunan $\mathrm{Pb}$.

Tingkat penurunan logam $\mathrm{Pb}$ tidak sebesar tingkat penurunan logam $\mathrm{Hg}$, hal ini diduga karena antara logam $\mathrm{Pb}$ dan protein juga membentuk ikatan metalloenzim seperti halnya pada ikatan antara logam $\mathrm{Cd}$ dengan protein. Tetapi tingkat penurunan logam $\mathrm{Pb}$ lebih besar daripada tingkat penurunan logam $\mathrm{Cd}$, hal ini dikarenakan kandungan logam Pb tidak sebesar kandungan logam Cd pada larutan KMK.

Dari hasil penelitian di atas, diperoleh informasi bahwa logam berat $\mathrm{Hg}, \mathrm{Cd}$, dan $\mathrm{Pb}$ membentuk ikatan kompleks dengan KMK. Ikatan logam berat yang terikat pada daging kerang berkompetisi dengan $\mathrm{H}$ di gugus $\mathrm{NH}_{2}$ pada larutan KMK untuk berikatan dengan protein. Pada setiap keseimbangan ion logam dan protein, ion logam akan berkompetisi dengan hidrogen untuk tempat ikatannya. Pernyataan ini didukung oleh Murtini et al. (2004), yang menyatakan bahwa kitosan mampu mengikat logam bervalensi dua atau divalen.

\section{KESIMPULAN}

Dari penelitian ini dapat disimpulkan bahwa karboksimetil kitosan dapat digunakan sebagai adsorben logam berat $\mathrm{Hg}$ dan $\mathrm{Pb}$ pada daging kerang

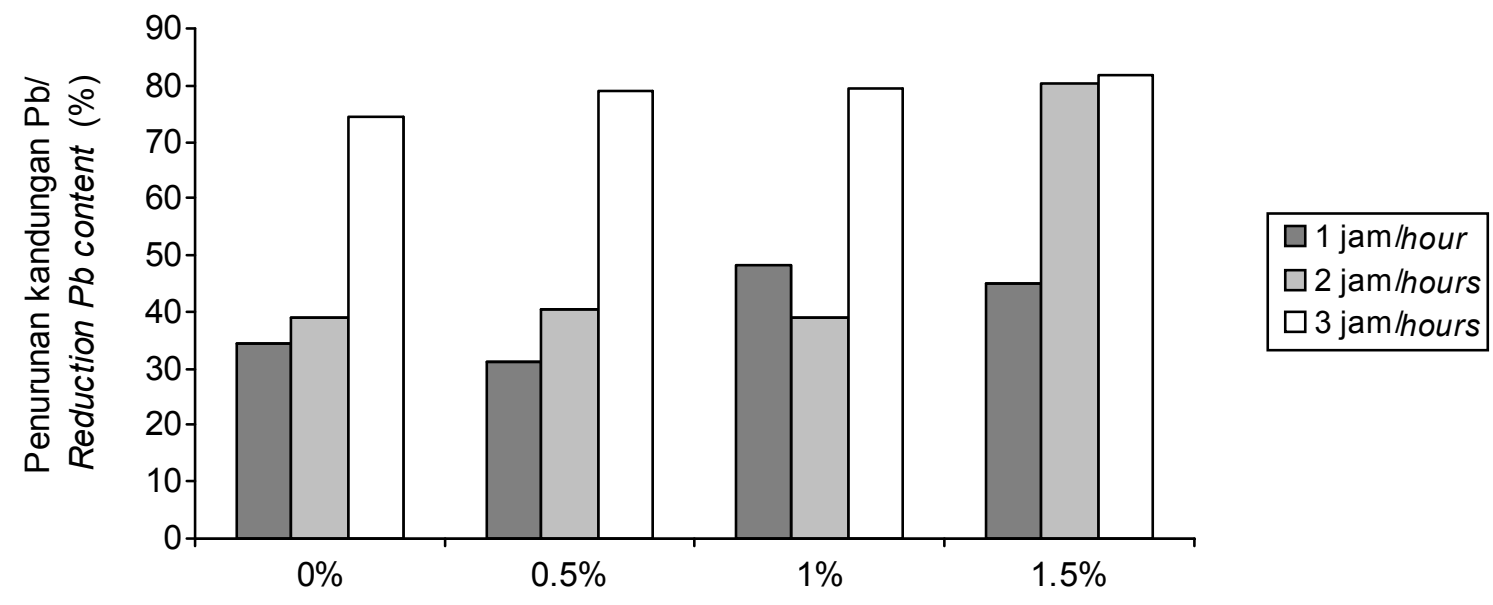

Konsentrasi KMK/CMCts concentrations

Gambar 3. Pengaruh perendaman larutan $\mathrm{KMK}$ terhadap penurunan kandungan $\mathrm{Pb}$ daging kerang hijau (Perna viridis Linn.).

Figure 3. Effect of dippng of green mussel (Perna viridis Linn.) dipping in CMCts solution on the reduction of $\mathrm{Pb}$ content. 
hijau (Perna viridis Linn.) meskipun tidak sebesar yang diharapkan. Penurunan logam Hg tertinggi dicapai dengan perendaman dalam larutan $\mathrm{KMK} 0,5 \%$ selama 1 jam, sedangkan penurunan logam $\mathrm{Pb}$ tertinggi adalah perendaman dalam larutan KMK 1,5\% selama 3 jam. Perendaman kerang hijau dalam KMK tidak efektif untuk menurunkan $\mathrm{Cd}$. Perendaman dalam akuades berpengaruh lebih besar daripada KMK dalam menurunkan kandungan logam berat dalam kerang hijau, diduga karena terjadinya leaching dari senyawa organik yang berikatan dengan logam berat.

\section{DAFTAR PUSTAKA}

Anonymous. 1998. Annual Book of ASTM Standard. United State 06.03: 313-315.

Darmono. 1995. Logam dalam Biologi Makhluk Hidup. UI Press, Jakarta. 139 pp.

Dwiyitno, Basmal, J., dan Mulyasari. 2004. Pengaruh suhu esterifikasi terhadap karakteristik karboksimetil kitosan (CMCts). J. Penel. Perik. Indonesia Edisi Pasca Panen. Pusat Riset Pengolahan Produk dan Sosial Ekonomi Kelautan dan Perikanan, Jakarta. 10(3): $67-73$.

Fessenden, R.J. dan Fessenden, J.S. 1995. Kimia Organik. Edisi ke-3, Erlangga, Jakarta. 527 pp.

Hutagalung, H.P. 1991. Pencemaran Laut oleh Logam Berat dalam Beberapa Perairan Indonesia. Puslitbang Oseanologi LIPI, Jakarta. p. 1-20.

Hutagalung H.P., Setiapermana, D., dan Riyono, S.H. 1997. Metode Analisis Air Laut, Sedimen dan Biota. Buku 2. Puslitbang Oseanologi LIPI, Jakarta. p. 5979.

Irwansyah, 1995. Efektifitas Khitin Sebagai Bahan Pengabsorbsi Residu Logam Berat Raksa (Hg) pada Kerang Hijau (Mytilus viridis). Skripsi. Fakultas Perikanan dan Kelautan, IPB, Bogor. 65 pp.

Kyoon, N.H., Won, J.N., and Meyers, S.P. 2003. Effect of time/temperature treatment parameters on de polymerization of chitosan. J. Appl. Polysacharide Sci. 87: 1890-1894.

LeCoultre, T.D. 2001. A Meta-analysis and Risk Assessment of Heavy Metal Uptake In Common Garden Vegetables. Thesis. Faculty of the Department of Environmental Health, East Tennessee State University, US. 64 pp.

Lestari, S. 2002. Penggunaan Na ${ }_{2}$ CaEDTA Dengan Konsentrasi dan Waktu yang Berbeda Sebagai
Upaya Penurunan Kandungan Logam Berat (Hg dan $\mathrm{Pb}$ ) pada Kerang Hijau (Mytilus viridis Linn.). Skripsi. Fakultas Pertanian Jurusan Perikanan, Universitas Padjajaran, Jatinangor. p. 1-20.

Marganof. 2003. Potensi Limbah Udang Sebagai Penyerap Logam Berat (Timbal, Kadmium, dan Tembaga) di Perairan. Unpublished. Pengantar ke Falsafah Sains Program Pascasarjana S3 IPB, Bogor. 8 pp.

Martin A., Swarbrick J., dan Cammarata, A. 1983. Farmasi Fisik: Dasar-Dasar Kimia Fisik dalam IImu Farmasetik. UI Press, Jakarta. 2: 1022-1036.

Murtini, J.T., Januar, H.I., dan Sugiyono. 2004. Upaya pengurangan logam berat $\mathrm{Hg}, \mathrm{Cd}$, dan As dengan menggunakan larutan kitosan. J. Penel. Perik. Indonesia Edisi Pasca Panen. Pusat Riset Pengolahan Produk dan Sosial Ekonomi Kelautan dan Perikanan, Jakarta.10(3): 7-10.

Muzzarelli, R.A.A., Roccheti, R., Stanic, V., and Weckx, M. 1997. Method of determination of degree of deacetylation of chitin and chitosan. In Muzzareli, R.A.A. and Peter, M.G. (eds.). Chitin Handbook. European Chitin Society. p. 109-132.

Oktavia, D.A., Wibowo, S., dan Fawzya, Y.N. 2005. Pengaruh jenis limbah rajungan dan rasio kitosan monokloro asetat terhadap karakteristik kaboksimetil kitosan. J. Penel. Perik. Indonesia Edisi Pasca Panen. Pusat Riset Pengolahan Produk dan Sosial Ekonomi Kelautan dan Perikanan, Jakarta. $16 \mathrm{pp}$.

Porsepwandi, W. 1998. Pengaruh pH Larutan Perendaman Terhadap Penurunan Kandungan $\mathrm{Hg}$ dan Mutu Kerang Hijau (Mytilus viridis Linn.). Skripsi. Fakultas Perikanan dan Kelautan, IPB, Bogor. 42 pp.

Rinaudo, M. and Domard, A. 1989. Solution properties of chitosan. In Braek, G.S., Anthonsen, T., and Stanford, P. (eds.). Chitin and Chitosan. Elsevier Science Publisher Ltd, NYC, US. p. 71-85.

Setyahadi, S. 2006. Pengembangan produksi kitin secara mikrobiologis. Prosiding Seminar Nasional Kitin Kitosan. Institut Pertanian Bogor, Bogor. p. 3340.

Wahyuni, M. dan Widiyanti, S. 2004. Reduksi kadar merkuri pada kerang hijau (Mytilus viridis) di Teluk Jakarta melalui metode asam serta pemanfaatannya dalam metode kerupuk. Prosiding Seminar Nasional dan Temu Usaha. Universitas Sahid, Jakarta. p. 206220. 
